\title{
3 From Competing to Aligned Narratives on Posted and Other Mobile Workers within the EU?
}

\author{
Mijke Houwerzijl and Annette Schrauwen
}

\begin{abstract}
The Treaty provisions on the free movement of workers provide rights to workers to move to, and accept work in other Member States, and to be treated as equal to 'national workers'. The enabling aspects of these provisions offer people a feeling of what it means to be an EU worker and allows them to determine freely how they are going to make a living. Clearly, the narrative of free movement of workers prevents that the focus is on the needs of the employer alone. In contrast, the posting of workers falls under the heading of EU free movement of services, and puts workers in a position of commodities or 'tools' with which service providers may provide their services in another Member State. It induces a narrative that puts the focus first and foremost on the economic interests of the employers, in their positions as temporary cross-border service providers. Focusing on the position of mobile workers in particular in low-wage sectors, this chapter sketches and juxtaposes the respective historical evolution of the narratives on posted and 'migrant' EU workers, while displaying their differing legal impact on workers' rights. This is accompanied by a look into the most recent developments in the posting of workers saga. What we assess is whether the pending proposal for 'targeted revision' of the Posted Workers Directive (PWD) substantially diminishes the differences between the two narratives. Does it broaden its perspective to the needs of workers next to those of employers? How would that relate to the framing that posted workers do not enter the labour market of the host state?
\end{abstract}

Keywords: posted workers directive, narratives posted and 'migrant' EU workers, revision PWD

Rijken, Conny and Tesseltje de Lange (eds): Towards a Decent Labour Market for Low Waged Migrant Workers. Amsterdam: Amsterdam University Press, 2018 DOI: 10.5117/9789462987555_HOUW 
In the historic narrative of EU free movement of workers, free movement rights were initially conceived in terms of the efficient exchange of the production factor labour, soon followed by a conception in terms of individual freedom that allowed workers to improve their living and working conditions and to improve their social advancement. The Treaty provisions on the free movement of workers provide rights to workers to move to, and accept work in another Member State and to be treated as equal to 'national workers'. The enabling aspects of these provisions form a species of social imagination that allows people to determine how they are going to live their lives. The narrative of free movement of workers prevents that the focus is on the needs of the employer alone.

In contrast, the posting of workers falls under the heading of EU free movement of services, and puts workers in a position of commodities or 'tools' with which service providers may provide their services in another Member State. The posting mechanism involves workers being temporarily employed in a 'host' Member State other than that where they normally work, while being taxed in and contributing to the social security system of the 'sending' Member State. Since the posting of workers takes place in the framework of the provision of services and not in the employee's capacity as a worker in his or her own right, it induces a narrative that puts the focus first and foremost on the needs of employers, in their position as temporary cross-border service provider.

Below, we will give an account of the historical evolution of the two contrasting narratives. The initial decision of the Court of Justice of the EU (hereafter CJEU or Court) in March 1990 in the case Rush Portuguesa, ${ }^{1}$ that posted workers were covered by the services provisions in the TFEU instead of the provisions on free movement of workers, was crucial. The main question that will be addressed throughout this chapter is whether the pending proposal for 'targeted revision' of the Posted Workers Directive (hereafter PWD) substantially diminishes the differences between the two narratives. Does it broaden its perspective to the needs of workers next to those of employers? How would that relate to the framing that posted workers do not enter the labour market of the host state?

The structure of this chapter is as follows: It starts by introducing several concepts stemming from discourse analysis that it loosely employs for the comparison of the respective narratives under free movement of workers 
and services as constructed by the CJEU. It will then sketch the (evolving) position of the 'mobile' worker under both narratives and identify which elements currently included in the narrative on posted workers are modified by the proposal for revision. Afterwards, it will turn to the revision process of the PWD in order to assess possibilities to 'upgrade' the narrative on posted workers. The chapter ends with some concluding remarks.

\section{$2 \quad$ Framing, Narratives, and their Limitations}

In Worlds between Words, Mark van Ostaijen shows the significance of discourses to understand institutional action and policy-making. ${ }^{2} \mathrm{His}$ study reveals that the outcome of a discursive struggle determines whether mobility or migration is seen as 'problem', 'solution', 'a return from the past', or as 'hope for the future'. ${ }^{3}$ Hence, it determines the starting point for institutional (in)action. This chapter borrows from his study the idea that the discursive perspective allows an insight into 'how actors create consistency and credibility to articulate legitimate claims. ${ }^{4}$ For example, the Court can be seen as an important actor in legitimising the current EU legal framework in which posted workers are situated, starting with its landmark ruling in Rush Portuguesa. Though the concepts 'frame' and 'framework' suggest a static concept by which subjects and issues are addressed, framing is more of a political process. The present chapter borrows the approach to framing as how specific language and concepts are used (naming), how involved groups are defined (classifying) and how a causal story with prescriptive solutions is constructed (narrating)', from Van Ostaijen. ${ }^{5}$ The authors of this chapter propose that discursive framing also influences legal categorisations and the legal framework. For instance, the statement of the Court that posted workers 'do not enter the labour market' of the host state influences the relative weight accorded to the protection of their rights in the development of further legal framework.

However, before looking at the respective narratives, one caveat must be made. It would go beyond the scope of this chapter to provide a thorough and balanced analysis of the 'full picture' of issues attached to cross-border

2 M.M.A.C van Ostaijen (2017), 'Worlds between Words: the politics of intra-European movement discourses,' Erasmus University Rotterdam, retrieved from http://hdl.handle.net/1765/99986.

3 Idem, p.188.

4 Ibidem.

5 Idem, p. 113 . 
(posted) labour mobility within the EU. Instead, the narratives reconstructed in this chapter are underpinned by a selection of remarkable judgments and other legal 'highlights', such as specific considerations or provisions of a Regulation or Directive, only. ${ }^{6}$ The selection made was inspired by the focus of this book on the challenges to create a decent labour market for low-waged work, involving mobile posted or migrant workers. In the EU, such challenges relate mainly to the movement of labour from 'low-wage' countries to 'high-wage' countries, in sectors such as agriculture, construction, road transport, and care, where companies are under high competitive pressure to 'search for ever cheaper labour'. In our view, a decent labour market in such sectors can only be achieved in a sustainable manner if the 'mission statement' of the ILO, that labour is not (merely) a commodity, is taken seriously for all (local, migrant, and posted) workers involved.

This limited approach helps to focus on the major elements in the narrative and makes a comparison possible. However, we acknowledge that it overemphasizes the position of low-waged mobile workers 'vis-à-vis' other mobile workers within the EU. Nevertheless, the political discourse in the last decade justifies such a selective approach. The (perceived threat of) social dumping, 'welfare tourism', and examples of abusive exploitation associated with cross-border labour mobility within the EU have provided a source of political tension. Currently, there is a fierce and ongoing debate about the costs and benefits of free labour mobility across the EU. In the United Kingdom, this debate played a crucial role in the victory for the advocates of 'taking back control over national borders'. In many other host countries, politicians blame 'Europe' for the undercutting of local workers and/or easy access to social welfare benefits. The scapegoating of Polish workers by the Dutch right wing PVV opening a hotline in the Netherlands in 2012 was a radical example of it. 7 Therefore, it is submitted that it is also in the interest of frontier workers with standard contracts, of high-wage international football players, of highly skilled professionals who work 'all over the globe' and all other mobile workers with relatively 'secure' and decent working conditions, to strive for a 'stronger framework

6 This means that the following issues will not be dealt with: the different types of posted workers, the position of international truck drivers, the exact scope of remuneration (such as the inclusion or exclusion of allowances, reimbursements for travel costs in the definition), the applicability of all or only general applicable collective agreements, the link between the PWD and Private International Law (PIL), as well as the link with regulations concerning the coordination of social security systems.

7 This provoked a European Parliament resolution of 15 March 2012 on discriminatory Internet sites and government reactions $(2012 / 2554(\mathrm{RSP})$. 
for posting in the EU, contributing to a fairer and deeper Single Market', ${ }^{8}$ and to make 'the free movement of people to be based on rules that are clear, fair for everybody and enforced on the ground'. ${ }^{9}$ Analysing and juxtaposing the narratives on free movement of workers and posting of workers from that angle brings out (or refreshes our collective memory of) interesting differences that could serve as an impetus for further steps to enhance the current legal framework.

\section{'Free movement of workers': An Almost Fully Consistent Narrative of Enabling Personal Development and Social Advancement for Workers}

In one of the earlier cases on the free movement of workers and Article 45 TFEU [then 48 EEC], Commission v France, the Court interpreted the provision as entailing 'the abolition of any discrimination based on nationality, whatever be its nature or extent, between workers of the Member States as regards employment, remuneration and other conditions of work and employment. ${ }^{\prime 0}$ What makes this judgment remarkable is that the Court added that the effect of nondiscrimination is not only enhancing the free choice to work in another EU country and being treated equally as national workers. It also has the effect of 'guaranteeing to the State's own nationals that they shall not suffer the unfavourable consequences which could result from the offer to, or acceptance by, nationals of other Member States, of conditions of employment or remuneration less advantageous than those obtained under national law, since such acceptance is prohibited."11

One could see this as framing the free movement of workers in functions of both the individual freedom to decide to take up employment in another Member State, and of a level playing field where remuneration and employment conditions cannot be used as means to displace local workers (often referred to as 'social dumping'). The individual freedom to take up employment anywhere in the EU on the condition of equal treatment, is

8 European Commission (2016), Revision of the Posting of Workers Directive-frequently asked questions, Strasbourg. Available at: http://europa.eu/rapid/press-release_MEMO-16-467_en.htm. 9 EU Observer (20 July 2016), 'Eastern EU states lose battle on workers' pay', Brussels. Available at: https://euobserver.com/economic/134433.

10 Case 167-73, Commission v France (French merchant seamen), [1974] ECR 359, para. 44. Italics added by the authors.

11 Ibidem, para. 45. See also C. Barnard (2014) 'Free movement of natural persons', in: C. Barnard and S. Peers (eds.), European Union Law, OUP p. 359. 
mentioned very often by the Court in subsequent cases on free movement of workers, ${ }^{12}$ whereas the guarantee that nationals of host States shall not suffer the negative consequences of free movement of workers is not. ${ }^{13}$ Still, it is interesting to note that the Court has also stressed this 'dual rationale' of the nondiscrimination principle in relation to other subjects. ${ }^{14}$

The Court's narrative partly equals that of Regulation (EEC)1612/68 on free movement of workers, now replaced by Regulation (EU) 492/2011. The preamble of the Regulation explicitly mentions 'social advancement' of the worker as one of the aims of free movement of workers. Furthermore, the Regulation has as its principal aim in the words of the Court, to ensure that 'in each Member State workers from the other Member States receive treatment which is not discriminatory by comparison with that of national workers by providing for the systematic application of the rule of national treatment as far as all conditions of employment and work are concerned. ${ }^{15}$ By granting entitlement to EU nationals to access the labour markets of the other Member States, these provisions are meant to be the main source (the 'cornerstone') of EU labour movement to another Member State. Pursuant to Article 7(4) of the Regulation, EU nationals who move as workers to another Member State are entitled to equal treatment with national workers as regards remuneration, dismissal, and other labour conditions in law laid down in collective or individual agreement, or any other collective regulation; and, should they become unemployed, reinstatement or reemployment, access to training in vocational schools and retraining centres, and the same social and tax advantages, whether or not attached to the contract of employment, ${ }^{16}$ the extension of which to workers from other Member States seems ‘suitable to facilitate their mobility within the

12 For a recent example, see Case C-566/15, Konrad Erzberger, ECLI:EU:2017:562, para. 33.

13 However, A-G Lenz explicitly relied on para. 45 of the French merchant seamen judgment in his opinion in the case 237/83 Prodest, [1984] ECR 3153, para 4. See in more detail, M.S. Houwerzijl (2005), De Detacheringrichtlijn'(PhD thesis), Deventer: Kluwer, pp. 64-66; and M. Houwerzijl (2014), 'Regime shopping across (blurring) boundaries' in S. Evju (ed.), Regulating Transnational Labour in Europe: The quandaries of multilevel governance. Oslo: Skriftserie nr. 196.

14 See Case 43/75, Defrenne II [1976] ECR 455, paras. 10-15, on equal treatment of men and women. A link was made to Art. 117 (now Art. 151 TFEU) on 'common action to ensure social progress and seek the constant improvement of living and working conditions'. See also the remark of A-G Dutheillet de Lamothe in Defrenne I (Case 80/70 [1971] ECR 445) about Art. 119 (now 141 TFEU) 'creating an obstacle to any attempt at "social dumping" by means of the use of female labour less well paid than male labour'.

15 Case 110/79, Una Coonen v. Insurance officer, [1980] ECR 1445, para. 6.

16 Regulation 1612/68 of the Council of 15 October 1968 on freedom of movement for workers within the Community, OJ English special edition 1968 II-475; Case 32-75, Anita Cristine v Société nationale de chemins de fer français, [1975] ECR 1085, para. 13. 
Community'. ${ }^{17}$ The preamble of the Regulation presents free movement of workers as 'a fundamental right for workers and their families', which, in the Court's view, is a 'general affirmation of the right of all workers to pursue the activity of their choice' within the Union, and could be 'an effective means of improving their living conditions. ${ }^{18}$

On the other hand, the Court's statement that local workers shall not suffer the unfavourable consequences of unequal treatment of incoming workers, deviates somewhat from Regulation 1612/68. The latter provided for possible measures in cases in which Member States would undergo or foresee disturbances of their labour market, which may seriously threaten the standard of living or the level of employment in a region or industry. In such a case, Member States could stop the information on vacancies (the machinery for vacancy clearance), but they were not allowed to limit access to employment. However, this provision, recognising that local workers in a certain industry or region might need some protection from free movement in specific cases, was never used and subsequently abolished in Regulation 492/2011. ${ }^{19}$

The Court's discourse on equal treatment as (always) protecting local workers from unfair competition became more seriously contested by the discourse used towards free movement of workers in the context of the Greek accession (and in the context of subsequent accessions with countries poorer than the existing Member States). The Accession Treaty included transitional provisions on free movement of workers allowing all Member States, including Greece, to impose work permits for a seven-year period. ${ }^{20}$ A joint declaration was added to the Accession Treaty that said that ' $\mathrm{T}] \mathrm{he}$ enlargement of the Community could give rise to certain difficulties for the social situation in one or more Member States as regards the application of the provisions relating to the free movement of workers.' In fact, the nine Member States feared that Greek workers would try to escape the high unemployment level in Greece, leading to an influx of 'cheap' Greek labour. ${ }^{21}$

The Court, in this respect 'overruled' by the Accession Treaty, had to acknowledge the fear of the Member States that a right to equal treatment in

\footnotetext{
17 Case 65/81, Franzesco and Letizia Reina v. Landeskreditbank Baden-Württemberg [1982] ECR 33, para. 12 .

18 Case 53/81, Levin v. Staatssecretaris van Justitie [1982] ECR 1035, para. 14 and 15.

19 Art. 20 of Regulation 1612/68.

20 Act concerning the conditions of Accession of the Hellenic Republic and the adjustments to the Treaties, OJ EU of 19.11.1979, L291/17, articles 45-48.

21 Available at: https://www.cvce.eu/content/publication/1999/1/1/61a2a7a5-39a9-4bo6-91f869ae77b41515/publishable_en.pdf.
} 
itself would not be enough to make sure local workers will not suffer unfavourable consequences from free movement. However, when it had to answer a preliminary question concerning these transitional provisions, it declared that the provision 'is to prevent disturbance of the labour market both in Greece and in the other Member States as a result of immediate and substantial movements of workers following accession ${ }^{\prime 22}$ and that, as such, it must be interpreted restrictively. Hence, it stuck to the narrative that equal treatment will, in principle, protect local workers from unfair competition, except in post-accession periods. Outside the context of accession, the Court has explicitly dismissed the argument that an increasing number of unemployed local workers in a specific sector would allow a Member State to prevent or hinder access of EU citizens and their family members to work in that sector. ${ }^{23}$

To sum up: the Court's narrative on free movement of workers is quite positive. It is beneficial for moving workers, who can improve their living conditions or obtain social advancement. Except for post-accession periods, it is not assessed as negative for the local workers, who are protected against unfair competition on remuneration or working conditions and social benefits via the principle of equal treatment.

We may wonder whether the choice for Brexit challenges this (last part of the) narrative. While on the one hand upholding firmly the stance that 'freedom of movement is non-negotiable as long as one is Member of the $\mathrm{EU}$ or if Britain wants access to the single market', ${ }^{24}$ the European Commission states that it has also 'learnt from Britain's vote to leave the EU that many Europeans fear globalisation and want the EU to provide more social protection in the internal market'. ${ }^{25}$ As one of the outcomes of this 'learning process', the Commission, in March 2016, launched a proposal to achieve a 'stronger framework for posting in the EU, contributing to a fairer and deeper Single Market'. ${ }^{26}$ However, there are no formal plans to reform the

22 Case 77/82, Anastasia Peskeloglou [1983] ECR 1086, para. 12.

23 Case 131/85, Emir Gülv. Regierungspräsident Düsseldorf, [1986] ECR 1583, para. 6 and 17; Case 9/88, Lopes da Veiga, [1989] ECR 2989, para 10. A similar restrictive approach is visible in the judgments on Vicoplus (joined cases C-307-309/o9 [2011, ECR I-453), Essent (C-91/13, ECLI:EU:C:2014:2206), and Martin Meat (C-586/13, ECLI:EU:C:2015:405). See for an explanation in particular A-G Bot, Opinion in Essent, paras. 102-110, 114, ECLI:EU:C:2014:312. See on Vicoplus, Houwerzijl (2014), n. 14, pp. 118-124. 24 See Donald Tusk (5 July 2016), 'Freedom of movement is non-negotiable if Britain wants access to single market', The Independent. Available at: http://www.independent.co.uk/news/ uk/politics/donald-tusk-says-access-to-the-single-market-means-britain-must-accept-eu-fourfreedoms-a7120191.html.

25 EU Observer (20 July 2016), n. 10. Available at: https://euobserver.com/economic/134433.

26 European Commission (2016) n. 9. Available at: http://europa.eu/rapid/press-release_MEMO16-467_en.htm. 
current 'acquis' on free movement of workers, even though the 2016 'new settlement' deal struck between the Council and the UK to 'prevent' Brexit included a safeguard mechanism acknowledging Member States' competence to limit 'flow of workers' and their access to social benefits in a host state. ${ }^{27}$ Apparently, lessons from Brexit do not (yet) include further questions on the narrative of free movement of workers. It is true that Directive 2014/54 ${ }^{28}$ was adopted with an aim to ensure better information about free movement rights and responsibilities, and to combat circumvention of those rules. Although a topical reminder that the right of freedom of movement for workers requires ensuring equality of treatment in fact and in law, ${ }^{29}$ it does not substantially change the positive narrative that nondiscrimination renders free movement beneficial for the moving worker and prevents, in principle, negative consequences for the local workers.

In order to understand why creating decent labour conditions for posted workers is one of the objectives in the Commission's strategy to create a deeper and fairer internal market, whereas reforming free movement of workers is not, ${ }^{30}$ we now turn to the narrative on that form of cross-border labour mobility within the EU.

4

\section{'Posting of workers': A Switch of Narrative towards a Focus on Service Provision}

This section illustrates how posted workers were eventually caught in the narrative on free provision of services. As early judgments of the Court of Justice in the cases Manpower and Van der Vecht ${ }^{31}$ show, employee posting was already a phenomenon in the late 1960 s and early 1970s. In the cases of Webb and Seco, the Court acknowledged that service providers could provide manpower or bring (non-national or non-EU) workers to do the job, and that Member States could apply their legislation or collective labour agreements

27 European Council Conclusions (19 February 2016), EUCO 1/16, Annex I section D and Annex VI.

28 Directive 2014/54/EU of the European Parliament and of the Council of 16 April 2014 on measures facilitating the exercise of rights conferred on workers in the context of freedom of movement for workers, OJEU of 30.4.2014, L 128/8. See also Section 6 below.

29 Recital 6 Regulation 492/2011.

30 Available at: https://ec.europa.eu/commission/priorities/internal-market_en.

31 Case 19/67, Van der Vecht [1967] ECR 345 and Case 35/70, Manpower [1970] ECR 1251. At stake was the practice of hiring (temporary agency) workers from a country with a 'cheaper' social security scheme, with the sole purpose of posting them to a Member State with a more expensive social security regime, which was, at that time, labeled abusive and 'social dumping'. 
relating to minimum wages to workers within their territory, no matter in which Member State the employer is established..$^{22}$ However, the disputes in Webb and Seco were about difference in treatment of the employers as service providers, and the Court did not rule on the applicability of the Treaty provisions of either free movement of workers or free movement of services on the employees.

Nevertheless, one can find in the obiter dictum in Webb that the employees may 'in certain circumstances be covered by the provisions of the free movement of workers', but that it does not prevent 'undertakings of that nature which employ such workers from being undertakings engaged in the provision of services'. This consideration seems to reflect the original narrative on posting of workers, laid down in secondary legislation of the 1960 s on the ambit of the freedom to provide services, wherein the following standard sentence, referring to the free movement of workers, used to be included in the Preamble: 'Whereas the position of paid employees accompanying a person providing services or acting on his behalf will be governed by the provisions laid down in pursuance of Articles 48 and 49 of the Treaty (now Articles 45 and 46 TFEU)'.33

In those days, as a main rule, it was stipulated that all workers, whether permanently or temporarily moving to another Member State, fell under the free movement of workers. Hence, all forms of workers' mobility of EU nationals were lumped together under the free movement of workers. ${ }^{34}$ Nonetheless, it was also acknowledged from the very beginning that the law on the free provision of services may interfere with the law on the free movement of workers. ${ }^{35}$ To make sure that a cross-border posted worker would not be denied the right to reside temporarily (not exceeding a year) in the host Member State, a special provision was laid down in Article 6(3) of Directive 68/36o/EEC, based on the free movement of workers. Undeniably, in this original approach, the status of the employing company - as crossborder service provider - was separated from the status of the posted worker.

32 Case 279/8o, Criminal proceedings against Alfred John Webb [1981] ECR 3305; Joined case 62 and 63/81, SECO v EVI, [1982] ECR 223, para 14.

33 Cited from old Council Directive 64/429/EEC (now repealed). For an overview of the other (old) Directives that contain this sentence, see Houwerzijl (2005/2014), n. 14, respectively p. 35, p. 102.

34 Evidenced by the texts and scope of old Regulations 1612/68, Regulation 1408/71, and old Directive 68/36o. See Houwerzijl (2005/2014), n. 14, respectively pp. 31-32, pp. 102-103.

35 See D. Vignes (1961), 'Le droit d'établissement et les services dans la C.E.E.' Annuaire Français de Droit International, 7 pp. 674-675; U. Everling (1963), Das Niederlassungsrecht im Gemeinsamen Markt, Verlag Franz Vahlen Berlin 1963 pp. 72-73. 
In its landmark judgment Rush Portuguesa, the Court abandoned the original narrative. It ruled that the situation of employees travelling with their employer to another Member State in order to carry out works on a temporary basis would fall under the scope of free movement of services. The Court's decision postdates the accession of Portugal. Rush Portuguesa, a Portuguese undertaking, had won a contract in France and wanted to carry out the work with its Portuguese workers. Under the transitional provisions of the Accession Treaty with Portugal, the provisions of free movement of workers did not apply to the Portuguese staff. The French authorities notified Rush Portuguesa of a decision to pay a fine for employing foreign workers in breach of the provisions of the French Labour Code. In proceedings for annulment of the decision of the French authorities, the undertaking argued that it was not the provisions of free movement of workers, but those of free movement of services that applied, and therefore its workers could not be hindered or prohibited from working in France. In answer to the preliminary questions of the referring judge, the CJEU decided not to apply the provisions of free movement of workers to posted workers, with the key argument that they did not enter the labour market of the host Member State.

Cleary, the context of the post-accession transition provisions played a major role in that decision. ${ }^{36}$ Under the transitional regime, the only way to bring the posted workers under the scope of EU law was to relocate them to the field of free movement of services. However, this had two consequences for the further narrative of posted workers. First, the argument that posted workers do not enter the labour market of the host state had to be made to show why, from a substantive point of view, it was justified to exclude them from the transitional provisions on the free movement of workers. Secondly, the free movement rights of posted workers had to be reformulated as deriving from that of the service provider: imposing conditions of obtaining a work permit for posted workers 'on the person (i.e. the employer in the sending state) providing services in another Member State discriminates against that person in relation to his competitors established in the host country [...], and moreover affects his ability to provide the service. ${ }^{37}$ The Court added in an obiter dictum that Member States may extend their mandatory labour law and collective labour agreements to posted workers, apparently to comfort

$3^{6}$ Indeed, the Court indicates that the transitional provisions in the Act of Accession are justified by a risk that the employment market of the host state might be disrupted when Portuguese workers and their family members seek access to the employment market of other Member States. In Case 9/88, Lopes da Veiga v. Staatssecretaris van Justitie, n. 24, predating Rush Portuguesa, the Court was more blunt. See para. 10.

37 Rush Portuguesa, para. 12. Italics added by the authors. 
France and possibly other host states that admission under free movement of services will not lead to a massive influx of workers under the guise of service provision, nor create social dumping. ${ }^{38}$ However, this consideration does not imply that posted workers have a right to equal treatment, only that Member States may extend domestic labour law provisions to them. ${ }^{39}$

The decision in Rush Portuguesa set the tone for framing the further case law on posted workers..$^{40}$ In Vander Elst,$^{41}$ a Belgian employer carried out works in France with his Moroccan employees, and disputed the obligation to pay fees for work permits to the French authorities with the argument that the Moroccan workers had already been issued with work permits in Belgium. The Court agreed and ruled that the obligation restricted the freedom to provide services. In its ruling, the Court implicitly sharpened the distinction between the narrative on free movement of workers and that on posted workers with three arguments. The first argument responds to the ratio of the French system of work permits, notably the regulation of access to the labour market of non-EU workers. The Court states that workers 'do not in any way seek access to the labour market' of the host state..$^{42}$ This rationale behind the 'status aparte' of posted workers is underpinned by the notions that they only work 'temporarily' or 'for a limited period' in the host state. The second argument is that EU law 'does not preclude Member States from extending their legislation, or collective labour agreements entered into by both sides of industry relating to minimum wages' to posted workers. ${ }^{43}$ Apparently, only the coverage by the minimum wage level in the host state is enough to protect posted workers and fair competition. The third argument is connected to the second, and relies on the 'underlying' applicability of the labour law of the country where the posted worker normally carries out his work: the application of that law 'in any event excludes any substantial risk of workers being exploited, or, of competition between undertakings being distorted. ${ }^{44}$

38 See L. Gormley (1992), 'Freedom of Establishment and Freedom to Provide Services: Workers and Services Distinguished,' European Law Review, 17(1) p. 63 and p. 66.

39 See also S. Evju (2010), 'Revisiting the Posted Workers Directive: Conflict of Laws and Laws in Contrast', CYELS, 12 p. 151 and p. 164.

40 Ibidem. See also, C. Barnard (2009), 'Internal market v. labour market: a brief history', in M. de Vos (ed.), European Union Internal Market and Labour law: Friends or Foes, Intersentia.

41 Case C-43/93, Vander Elst v. Office des Migrations Internationales, [1994] ECR I-3818.

42 Idem, para. 21.

43 Idem, para. 23.

44 Idem, para. 25. In VanderElst, the Court refers to the applicable law of the country of establishment of employer, but from a private international law perspective (currently in the Rome I Regulation 593/2008), which is not elaborated upon in this Chapter, it depends on the 
As is well-known, it was the landmark judgment in the case Rush Portuguesa that paved the way for the legal base of the PWD. ${ }^{45}$ In the first half of the 1990s, in the context of the social dimension of the Delors' project 'Europe 1992', the proposal for a Directive on the Posting of Workers was launched. ${ }^{46}$ In order to promote a true single market, a framework of rules for posted workers would have to be created to avoid unfair competition. The proposal led to a six-year period of fierce debates in European Parliament and Council. ${ }^{47}$ The debates focussed in particular on the extent to which host Member States must be allowed, or should be required, to apply their mandatory wage provisions and other working conditions to workers posted to their territory. Another issue concerned the legal basis of the Directive, which was found in the Treaty provisions establishing the freedom to provide services. ${ }^{48}$ From a political point of view, the undoubted merit of this legal basis is that it facilitated a qualified majority vote. Without this, the PWD proposal would probably have stranded. ${ }^{49}$ Still, from a legal point of view, the worrying implication of the choice of (only) this legal base is that it suggests that the PWD is purely intended to facilitate the cross-border provision of services. That it also serves to protect employees and to create a level playing field (and no unfair competition) is by no means evident from its legal base.

individual situation of the posted worker whether the law of 'the (common) country of origin' applies or the law of another country. The main connecting factor is supposed to be 'the habitual country of work'. See A. van Hoek and M. Houwerzijl (2016), 'Where do EU mobile workers belong, according to Rome I and the (E)PWD', in H. Verschueren (ed.), Residence, employment and social rights of mobile persons: on how EU law defines where they belong, Intersentia; see also A. van Hoek (2018), 'Re-Embedding the Transnational Employment Relationship: A Tale about the Limitations of (EU) Law?', Common Market Law Review 55, no. 2, 449-87. Available at: https:// papers.ssrn.com/sol3/papers.cfm?abstract_id=2886430.

45 See R. Zahn (2017), 'Revision of the Posted Workers Directive: a Europeanisation Perspective', Cambridge Yearbook of European Legal Studies 2017 5, p. 5. See also M.S. Houwerzijl (2014), n. 14. While Evju traces a much longer and more complex background to the Directive, he considers the decision in Rush Portuguesa a 'booster' for the PWD in S. Evju (2010), n. 40, p. 154.

46 The first documents on what would become the PWD referred to the Community Charter for social fundamental rights of workers, see COM (89)568. See, for an extensive historical account, M. S. Houwerzijl (2005), n. 14, p. 85. Also see J. Cremers, J. E. Dølvik, and G. Bosch, (2007-6) 'Posting of workers in the single market: attempts to prevent social dumping and regime competition in the EU', Industrial Relations Journal, pp. 524-541 and S. Evju (2010), n. 40, p. 160.

47 See, for instance, OJ 15, C 166/123.6.95, no. 4-464/204 and no. 4-464/206.

48 Articles 57 (2) and 66 EC [now 53(1) and 62 TFEU].

49 See, about the political circumstances of the early 1990s (in which the British Conservative Government tried to veto almost everything that had to do with social policy) that influenced the political fate of the posting directive, M. Biagi (1998), 'The "Posted Workers' EU Directive"', in R. Blanpain (ed.), The Bulletin of Comparative Labour Relations in the European Union, p. 175. 
To sum up, it may be noted that the framing of the status of posted workers by both the Court and the legislature was probably highly influenced by the political and legal 'momentum'. The services provisions in the Treaty conveniently allowed the Court to bring posted workers from new Member States under the scope of EU law in a situation in which free movement of workers was subjected to transitional provisions. The services provisions also conveniently allowed the legislature a qualified majority voting, necessary to adopt the PWD. However, the result seems far from satisfactory with regard to the protection of both posted and local workers: (Re)Framing posted workers under the free movement of services deprived posted workers with EU citizenship of their self-standing right to free movement in their capacities as workers. The services narrative contains no reference to improvement of living conditions nor to social advancement of posted workers. Protection only goes as far as 'core host labour standards' and exclusion of exploitation. Neither does this narrative pay much attention to possible displacement of local workers, as it puts the emphasis on fair competition between undertakings/service providers and consequently on equality of treatment between undertakings, omitting any reference to equality of treatment between posted and local workers.

\section{$5 \quad$ Interpretation of the PWD: Strengthening the Narrative Based on Service Provision}

As stated in its recital 5 , the PWD means to reconcile the exercise of companies' fundamental freedom to provide cross-border services under Article 56 TFEU, on the one hand, with the need to ensure a climate of fair competition and respect for the rights of workers, on the other. However, in Rüfert,$^{50}$ the Court seems to have created a priority between the three goals, emphasising that the objective of the Directive is 'in particular to bring about the freedom to provide services'. ${ }^{11}$ Although fitting well with the legal basis of the PWD, $5^{2}$ this emphasis of its exclusive falling within the scope of free movement of services, clearly deviates from how the European

50 Case C-346/o6, Rüffert [2008] ECR I-1989, para 36.

$5^{1} \quad$ Evju (2010), n. 40, pp. 169-170.

52 See also S. Reynolds (2016), 'Explaining the constitutional drivers behind a perceived judicial preference for free movement over fundamental rights', CMLRev. 3 p. 643 . 
Commission originally presented the proposal for the PWD as part of the development of a social dimension of the internal market. ${ }^{3}$

In order to achieve its aims, the PWD coordinates Member States' legislation in a way that it provides a core of mandatory rules on minimum protection with which employers who post workers to the Member State, in which the service is to be provided, must comply in the host country. This is laid down in Article 3 of the PWD. Article 3(1) states that Member States are to ensure that undertakings falling within the scope of the PWD guarantee workers posted to their territory, the terms and conditions of employment laid down by mandatory law, including collective agreements that have been declared universally applicable insofar as they concern the construction sector referred to in the Annex of the PWD. These 'host state standards' concern the duration of the work; rest periods and holidays; minimum rates of pay; health, safety, and hygiene at work; the conditions of hiring out workers; protective measures for pregnant women, for women who recently gave birth, for young people and children; and equality of treatment between men and women. Hence, Article 3(1) PWD determines the nature of the labour standards that must be applied in the host state, but not the substance of these standards.

However, this material scope of the PWD got a strict interpretation by the CJEU in the triptych Laval, Commission v. Luxemburg, and Rüffert cases. ${ }^{54}$ According to Article 3(10) first indent of the PWD, the host Member States may add public policy provisions on other subjects than those explicitly listed in art. 3(1) PWD. This was part of the delicate political compromise needed to get the PWD adopted. In Commission v Luxembourg, the Court has chosen a restrictive interpretation of this provision, by cutting back the margin of appreciation Member States have in defining what is to be understood under public policy. The CJEU has pointed out that the concept of public policy, firstly, comes into play where a genuine and sufficiently serious threat affects one of the fundamental interests of society and, secondly, since it is a justification for a derogation from a fundamental principle of the Treaty, that it must be narrowly construed.

In Laval, the main focus of the Court's judgment was whether the collective action, in the form of a blockade taken by trade unions in this case, was compatible with the EU rules on the freedom to provide services. The CJEU ruled that the 'right to take collective action for the protection of the 
workers of the host state against possible social dumping may constitute an overriding reason of public interest', which could justify an infringement of free movement of services. However, in this case, it did not, since the prevailing Swedish collectively bargained labour standards were deemed to be not 'sufficiently precise and accessible' for the foreign service provider to know its obligations in advance. Hence, the Court did not accept the method of implementation of the PWD in Sweden, where the applicable rates of (minimum) pay were negotiated on a case by case basis through the social partners, without being supplemented by legislation providing for universal applicability. Furthermore, the Court pointed out that the PWD does not allow the host Member State to make the provision of services in its territory conditional on the observance of terms and conditions of employment that go beyond the mandatory rules for minimum protection, as laid down in Art. 3(1) PWD. It is this consideration that the phrase often used in literature, the 'floor' of minimum labour conditions in the host state has (also) become 'a ceiling' stems from. ${ }^{55}$ Clearly, the Court considers the PWD to be about protection of workers only in a secondary sense, noting that the minimum protection in force, in the host state, enables the posted workers 'to enjoy better terms and conditions of employment in the host member state'. ${ }^{6}$ This phrase is a far cry from the improvement of life conditions and social advancement' in the narrative on free movement of workers.

The judgments of the Court fueled intense scholarly and public debate. ${ }^{57}$ Moreover, the European Commission had changed its initial approach to the PWD as well, ${ }^{8}$ as became clear in the debate on the then draft Services Directive. ${ }^{59}$ The controversies surrounding the Services Directive, back then commonly referred to in the popular press as the 'Bolkestein Directive', ${ }^{60}$ together with the EU's enlargement with Middle and Eastern European countries, have played an important role in drawing attention to the limited impact of the social dimension of the PWD. ${ }^{61}$ Instead, the narrative that

55 S. Evju (2010), n. 40, p. 177 .

56 Laval para. 76 and 77 .

57 The 'Laval-quartet' gave rise to numerous conferences among scholars and policymakers and led to a 'tsunami' of (working) papers and articles in Academic journals. See also many ETUC press releases and reports on the aftermath of this case law.

$5^{8}$ J. Cremers, J. E. Dølvik, and G. Bosch, (2007), n. 47, pp. 538-539.

59 See, for instance, 14.02.2006 Commissioner Charlie McCreevy's Statement on the Services Directive at the European Parliament Plenary session of February 2006; SPEECH/o6/84.

6 o Bolkestein was the name of the responsible Commissioner at the time. In France, however, the draft Services Directive was nicknamed Frankenstein Directive in the popular press.

61 See, for an acknowledgement of the 'integration fatigue' and '(single) market fatigue' in the old Member States in western Europe due to e.g. the enlargements, M. Monti (May 2010), A new 
posting of workers was in particular to bring about the freedom to provide services was reinforced.

At the same time, the language remained such that posted workers were deemed (1) to not enter the labour market of the host state, (2) to not compete with local workers because of the application of a set of core host labour standards, and, (3) to be protected against exploitation by the labour rules applicable to their employment contract with their employer in the 'sending' state.

\section{Acknowledgement that Protection against Exploitation is Largely 'a fairy tale'}

The bursts in this predominant narrative on the PWD started with its third limb, which was contested and eventually declared fictitious around 2011. By that time, studies had convincingly shown that there is, in practice, a huge lack of control, monitoring, and cooperation among Member States, and that enforcement of minimum terms and conditions of employment is poor, e.g. on wages, working time, and costs of housing and transport. ${ }^{62}$ Anecdotal evidence from media has been confirmed and elaborated upon by academic and policy research. Studies of Wagner and Berntsen based on interviews with e.g. foreign workers situated at the building sites of the European Central Bank in Germany and the 'Eemshaven' in the Netherlands, as well as in workplaces in the meat sector and the supermarket distribution centres, clearly show exploitative practices in combination with the fact that cross-border mobile workers concerned, most often, do not even know their legal status. ${ }^{63}$

strategy for the single market, at the service of Europe's economy and society, Retrieved from: http//:ec.europa.eu/bepa/pdf/monti_report_final_10_05_2010_en.pdf.

62 See A.A.H. van Hoek and M.S. Houwerzijl (2011), Comparative Study on the legal aspects of the posting of workers in the framework of the provision of services in the European Union, Report to the European Commission; J. Cremers (2011), 'In search of cheap labour in Europe', CLR studies 6; J. Cremers (2011), In Search of Cheap Labour in Europe: Working and living conditions of posted workers, Brussels: CLR/EFBWW/International Books.

63 L.E. Berntsen (2015), Agency of labour in a flexible pan-European labour market: A qualitative study of migrant practices and trade union strategies in the Netherlands Groningen (PhD Thesis) Groningen: University of Groningen, SOM research school; and I. Wagner (2015), Posted Work and Deterritorialization in the European Union: A study of the German Construction and Meat Industry, (PhD Thesis) Groningen: University of Groningen, SOM research school. See also A. van Hoek (2017), n. 45 and literature cited there. 
It is interesting to note that these findings about the 'real' situation of lowwaged mobile workers within the EU, indicate that the effective application and enforcement of workers' rights under the narrative on free movement of workers, is also far from guaranteed. Especially in the area of provision of manpower, the problem of combating illegal activities is encountered. These forms of abuse are not specific to posting. The illegal intermediaries may be established both in the country of recruitment (leading to posting) or in the county of work (leading to free movement of workers). Several reported cases of abuse concerned migrant workers or (bogus) self-employed. ${ }^{64}$ These cases involve social dumping in its purest form - with no respect for either the protective system of the 'sending' country or that of the host country. In the field of free movement of workers, the EU legislator adopted Directive $2014 / 54$ to enhance effective enforcement. ${ }^{65}$ To remedy the monitoring and enforcement lacunae under the posting of workers narrative, a proposal for the 'Posting of Workers Enforcement Directive' (PWED) was launched in 2012 and - after initial fierce resistance of 'sending countries' - adopted on 15 May 2014. ${ }^{66}$ Its name acknowledges that the PWD did not guarantee in practice any protection against abusive and exploitative practices. ${ }^{67}$

The PWED can be seen as only a minor shift in the narrative on posted workers. It did not change anything to the second dimension of the narrative: posted workers are still only guaranteed a core of substantive minimum rights in the host state. ${ }^{68}$ Regarding the first dimension, Article 4 of the PWED provides some 'ammunition' to attack the presumption that posted workers do not have access to the labour market of the host state. The provision lists elements that can be used by labour inspectorates and other stakeholders to check whether a posting is genuine in that respect, and

64 See Van Hoek and Houwerzijl, n. 63, pp. 50-6o. More recently, the European Agency on Fundamental Rights (FRA) (2015) called for 'zero tolerance for severe forms of labour exploitation' in its report on Severe Labour Exploitation: Workers Moving within or into the European Union, States' Obligations and Victims' Rights, Brussels.

65 See also above, n. 30.

$66 \mathrm{COM}(2012)$ 131, emphasis added by the authors. The proposal was adopted as Directive 2014/67/EU of the European Parliament and of the Council of 15 May 2014 on the enforcement of Directive 96/71/EC concerning the posting of workers in the framework of the provision of services and amending Regulation (EU) No 1024/2012 on administrative cooperation through the Internal Market Information System ('the IMI Regulation') OJ L159/11 of 28.5.2014.

67 However, the 'tools' provided for combating abuse in the PWED do not seem to be very powerful.

68 Although the Court seems to have broadened the interpretation of the concept of 'minimum rates of pay' in Art. 3(1) PWD in its Judgment on Case 396/13 (Sähköalojen ammattiliitto ECLI:EU:C:2015:86) and with the Judgment in C-115/14 (Regiopost ECLI:EU:C:2015:760) the judgment in Rüffert was (de facto) 'softened'. 
whether the employer of the posted worker is really established in the 'sending' country, instead of being a so-called letterbox company or empty shelf, purely established to enable posting of workers from a country with low wages, taxes, and social security contributions. ${ }^{69}$ At the same time, the 'status aparte' of posted workers versus workers using the free movement of workers regime, was emphasized by recital two of the PWED, which states: 'It is necessary for the purpose of the posting of workers to distinguish this freedom from the free movement of workers'..$^{\circ}$

\section{The Targeted Revision Proposal: Towards a New Narrative on the Balance of Rights in the PWD?}

Contestation of the narrative on posted workers did not stop with the adoption of the PWED. In March 2016, the Commission launched a proposal for a targeted revision of the PWD.$^{71}$ According to the explanatory memorandum, the main aims for the revision are ensuring the smooth functioning of the single market and stopping 'unfair competition' on wage costs and working conditions, reflected in the mantra 'same pay for the same work in the same place'. This mantra clearly contests the second dimension of the narrative on posted workers as not competing with local workers due to the application of minimum protection provisions of the host state. How can this be explained?

According to Martin Ruhs, migrant rights cannot 'be comprehensively analysed and debated without a discussion of the role and interests of the state in granting, as well as restricting, migrant rights. ${ }^{72}$ The validity of this statement becomes particularly clear in the process which set the targeted revision process in motion. In a letter of Ministers from seven countries

69 See extensively on this phenomenon and how to combat it: M. Houwerzijl, E. Traversa, and F. Henneaux (December 2016), A hunters game: How policy can change to spot and sink letterbox-type practices, Brussels, commissioned by the ETUC.

70 This recital reads in full: 'The freedom to provide services includes the right of undertakings to provide services in another Member State, to which they may post their own workers temporarily in order to provide those services there. It is necessary for the purpose of the posting of workers to distinguish this freedom from the free movement of workers, which gives every citizen the right to move freely to another Member State to work and reside there for that purpose and protects them against discrimination as regards employment, remuneration and other conditions of work and employment in comparison to nationals of that Member State' (emphasis added).

$71 \operatorname{COM}(2016) 128$ final of 8 March 2016.

72 Martin Ruhs (2013), The Price of Rights: Regulating International Labour Migration, Princeton University Press, ebook, p. 23. 
from Northwest Europe, a revision of the PWD was pleaded according to the principle of 'equal pay for equal work in the same place'. ${ }^{73}$ In their letter to the Commission, the host states make clear that they are worried about unfair competition: '[...] currently employers of posted workers may enjoy an unfair advantage vis-à-vis employers in the host country'.74 However, they not only focus on equality of treatment between undertakings, but consider the position of the workers as well: 'In our view, fair competition is important to both cross-border workers and cross-border employers, as well as regular workers and employers in the host Member States. ${ }^{75}$ They seem to suggest, similar to the narrative on free movement of workers, that equal treatment protects local workers (and companies alike) from unfair competition on remuneration or working conditions. Also, they signal that, in some cases, services provided by posted workers have transformed into services of semipermanent nature with a real and lasting presence on the domestic labour market. Thereby, these countries at least partially, and implicitly, contest the first dimension of the narrative that posted workers do not enter the labour market of the host state.

However, others still stick firmly to the said two dimensions of the narrative. In a letter of Ministers from nine countries, mainly from Middle and Eastern Europe, it was argued that it is too early to revise the PWD since the implementation period of the PWED was only finished in June 2016. These Ministers want to wait and see what the impact of the PWED will be. Furthermore, they argue that 'the alignment of wages across Member States should come as a consequence of further economic development and not from the Union's legislative action. ${ }^{76}$ This is a nice way of saying that they feel their undertakings should be able to compete on wages until the difference in wage costs has decreased. Hence, the sending states stick mainly to (their reading of) the services narrative by expressing the concern 'that the principle of equal pay for equal work in the same place may be incompatible with the single market, as pay rate differences constitute one legitimate element of competitive advantage for service providers'.77 The proposal itself was also attacked: fourteen parliamentary chambers

73 Available at: https://www.rijksoverheid.nl/documenten/brieven/2015/o6/19/brief-aaneurocommissaris-thyssen-over-de-detacheringsrichtlijn.

74 Idem, p. 1.

75 Idem, p. 2.

76 Communication from the Commission on the proposal for a Directive amending the Posting of Workers Directive, with regard to the principle of subsidiarity, in accordance with Protocol No2, $\operatorname{COM}(2016) 505$ final of 20.7.2016, at 4.2.1.

77 Idem, under 3.1. 
from eleven Member States have drawn the yellow card, most of them, apparently, because they feel the proposed amendments go against the idea of an internal market and competitiveness. ${ }^{7}$ However, the Commission has decided to maintain the proposal as it is.

The proposal for targeted revision of the PWD distances itself from the narrative as developed thus far in several ways. First of all, the minimum wage guarantee is deemed no longer enough to protect a level playing field, and it is replaced by a guarantee of equal remuneration, so all elements of remuneration that are mandatory apply to both local and posted workers. ${ }^{79}$ These elements include thirteenth month allowances, travel expenses, or compensation for work during public holidays or night work. Secondly, the proposal contains the provision that whenever the anticipated or effective period of posting exceeds 24 months, posted workers will be protected by at least the compulsory labour law rules of the host state. ${ }^{80}$ However, the proposal of the French president Macron in June 2017 to halve the legal limit to twelve months, ${ }^{81}$ has been endorsed in the Council meeting of 23 October $2017 .{ }^{82}$ Remarkably, such an introduction of a temporal limit to posting clearly abandons the current rationale behind the PWD that all posted workers would only work 'temporarily' or 'for a limited period' in the host state. Hence, this is an implicit recognition that, after a certain defined period of time, posted workers do enter the labour market of the host state. ${ }^{83}$

One might conclude that important elements of the narrative on posted workers, as belonging in the category of free movement of services, are

78 Thomas Weber (14 May 2016), 'Third time's a charm? National Parliaments form bloc against posted workers directive,' Leiden Law Blog, available at http://leidenlawblog.nl/articles/ third-times-a-charm-national-parliaments-form-bloc-against-posted-workers-directive.

79 COM (2016) 128 final, art. 1(2) of the proposed Directive, amending art. 3 of the PWD. The explicit exclusion of supplementary occupational retirement pension schemes remains.

80 Idem, art. 1(1) of the proposed Directive, adding art. 2 a to the PWD.

81 See e.g. http://www.euractiv.com/section/economy-jobs/news/macrons-proposals-wreakhavoc-on-posted-worker-negotiations/ and https:/www.euractiv.com/section/economy-jobs/ news/france-seeks-last-minute-support-for-posted-workers-bill/.

82 With a possibility for a six-month extension in exceptional cases. Proceedings of EPSCO Council meeting, Interinstitutional File: 2016/0070 (COD), Brussels 24 October 2017.

83 More explicitly, the proposed recital 8, p. 4, reads: 'Posting is of a temporary nature and the posted worker usually returns to the country of origin after the completion of the work for which he has been posted. However, in view of the long duration of certain postings, and in acknowledgment of the link between the labour market of the host country and the workers posted for such long periods, it is necessary to provide that, in case of posting lasting for periods longer than twelve months, host countries should ensure that undertakings posting workers to their territory guarantee an additional set of terms and conditions that are mandatorily applicable to workers in the Member State where the work is carried out' (emphasis added by the authors). 
gradually erased from that narrative. Nevertheless, the initial decision of the Court in Rush Portuguesa that posted workers fall (only) within the scope of the services provisions still stands. In the explanatory memorandum accompanying the proposal for a targeted revision, the Commission argues that, because this is a revision, the legal basis must be identical to that of the PWD, hence the free movement of services provisions 53(1) and 62 TFEU. It is questionable whether the fact that this is a revision, is in itself conclusive for the exclusive use of the free movement of services provisions as legal basis. ${ }^{84}$ According to an opinion of the Committee on legal affairs of the European Parliament in June 2017, adding a legal basis is possible. ${ }^{85}$ In an examination of the measures that Article 46 TFEU allows the Union to adopt, on the free movement of workers and on facilitating the functioning of a common labour market, the Committee concludes that these do not correspond with the aim and content of the proposal. In order for this article to be applicable as legal basis, a wholly different piece of legislation would have to be envisaged. However, the Committee has opined that Article 153 TFEU, providing the EU with (shared) competences in the field of social rights should be added as legal basis, if the European Parliament wants to reinforce emphasis on the social protection of posted workers. In its adopted report, the Committee on Employment and Social Affairs of the European Parliament has indeed proposed to do so. ${ }^{86}$ Unfortunately, the - at the time of finalising this Chapter - recent compromise reached in the so-called trilogues ${ }^{87}$ does not include the broadening of the legal basis of the PWD. ${ }^{88}$ Therefore, we can expect the

84 See: C-271/94 (Edicom [1996] ECR I-1689) or 242/87 (Erasmus [1989] ECR 1425), and, in general, R.H. Van Ooik (1999), De keuze der rechtsgrondslag voor besluiten van de Europese Unie (PhD Thesis), Kluwer pp. 101-102. Still, DG Employment, Social Affairs, and Inclusion leads the process of revision, not DG Internal Market.

85 Available at: http://www.europarl.europa.eu/sides/getDoc.do?pubRef=-//EP// NONSGML+COMPARL+PE-604.710+02+DOC+PDF+Vo//EN\&language=EN.

86 See adopted report with amendments, Rapporteurs: Elisabeth Morin-Chartier, Agnes Jongerius, A8-0319/2017, Brussels 19 October 2017. Available at: http://www.europarl.europa. eu/committees/en/empl/draft-reports.html?ufolderComCode=EMPL\&ufolderLegId=8\&ufold erId=05991\&linkedDocument=true \&urefProcYear=\&urefProcNum=\&urefProcCode $=$.

87 Interinstitutional negotiations between the European Parliament, the Council, and the Commission. See for an overview of the issues that were on the table EU Observer (25 October 2017), 'EU posted workers face hurdles', Brussels, https://euobserver.com/social/139625.

88 See Joint Statement on the Posting of Workers Directive and Fact sheet - Towards fair labour mobility: Revision of EU posting of workers rules (1 March 2018). Available at: http://ec.europa.eu/ social $/$ main.jsp?langId=en\&catId=471\&newsId=9062\&furtherNews=yes . At the time of writing this Chapter the legislative text was not yet published at the European Commission's website. The provisional agreement still needed to be confirmed by EU member states' permanent 
Court to keep interpreting a revised PWD first and foremost in the light of free movement of services. ${ }^{89}$

\section{To Conclude: What about the Workers?}

The (political compromises on the) proposed revision of the PWD would clearly bring the narrative on posted workers more in line with the Court's narrative on free movement of workers. Indeed, it acknowledges that equal treatment between workers prevents unfair competition, which is an important step in the right direction. However, there is no reference made in the adjusted narrative on posting of workers that acknowledges potential beneficial aspects of this form of free movement for moving posted workers in their own right, notably to improve their living conditions or to obtain social advancement. It is indeed questionable whether this would be achievable without amending the legal basis of the PWD with a provision based on the free movement of workers, which would imply an acknowledgement that (at least many low-waged) posted workers do enter the labour market of the host state. ${ }^{90}$

Interestingly, recent empirical research has indicated that posted workers themselves do (sometimes) feel that moving as a posted worker allows them 'to improve their position and the future of their children in terms of socio-economic status, education and care,' even if they have to accept unequal remuneration, compared to local workers of the host state, or if they have to comply with poor working or housing conditions..$^{11}$ This stance, sometimes boldly phrased as 'the point of view of the posted worker from post-communist states', has also been defended from a

representatives (COREPER) and adopted in the European Parliament's Employment and Social Affairs Committee. Meanwhile, the revised directive has been officially approved by Parliament and Council on 28 June 2018 (see: PE 182018 REV 1).

89 Nevertheless, in recent case law the Court has paid a bit more attention to the social protection of workers of service providers, see Case C-115/14, Regiopost GmbH \& Co. KG v. Stadt Landau in der Pfalz, ECLI:EU:C:2015:760 and Case C-396/13, Sähköalojen ammattiliitto ry v Elektrobudowa Spolka Akcyjna ECLI:EU:C:2015:86.

90 See Section 7 above for the negative opinion of the Committee on legal affairs of the European Parliament on adding a legal base based on Article 46 TFEU.

91 M. van Ostaijen, U. Reeger, and K. Zelano (2017), 'The commodification of mobile workers in Europe - a comparative perspective on capital and labour in Austria, the Netherlands and Sweden', Comparative Migration Studies 5(6) p. 17. See also Berntsen, n. 64, above. On the other hand, there is also ample research that indicates dissatisfaction of the workers involved with abusive and exploitative working conditions. 
normative point of view. In particular, while acknowledging that social dumping and 'a race to the bottom' may occur in situations of posting, Kukovec and Leczykiewicz argue that these disadvantages, which (in their view) mainly go against the interests of the wealthier 'central' Member States and their workers, are outweighed by the interests of the workers from the new, 'peripheral' Member States to use their one and only comparative advantage - the possibility to compete on the basis of lower labour costs. ${ }^{92}$

Remarkable in this respect, is the statement of Leczykiewicz that 'employment opportunities on the Swedish and Finnish market in no way 'belong' to Swedish and Finnish workers. ${ }^{93}$ In relation to the posting of workers narrative, her argument sits uneasily with the legal fiction that posted workers do not have access to the labour market of the host state and (therefore?) cannot be deemed job seekers (and hence not migrant workers in the meaning of Art. 45 TFEU). In the opinion of Leczykiewicz, the Finnish and Swedish workers would no longer be legitimised to defend their system against underbidding by outsiders. Such a radical form of 'transnational solidarity' by allowing workers to compete on wage levels and hence give them a right to 'self-exploitation' - runs counter to goals and underpinnings of labour law, enshrined in the free movement of workers narrative. ${ }^{94}$ Acceptance of such self-commodification might, in the long run, not be sustainable, once the worker from the 'new' Member State stays for a longer period in the host Member State, and actually becomes more embedded in this state (by starting a family life, hiring or buying a house, having an accident, needing medical help, etc.). Moreover, as noted by Bernaciak, although in the short-term, posted workers may profit from dumping strategies, in the long run, dumping practices not only lead to the erosion of employment protection systems in the host states, but might also hinder the gradual improvement of wages and working conditions in the poorer sending countries. ${ }^{95}$

92 See D. Leczykiewicz (2015), 'Conceptualizing conflict between the economic and social in EU law after Viking and Laval', in M. Freedland and J. Prassl (eds.), EU law in the Member States: Viking, Laval and beyond, Oxford, Hart Publishing; and D. Kukoveck (2014), 'Hierarchies as law', Columbia Journal of International Law, 21 p. 142. See also A. Somek (2011), The social question in a transnational context', LSE 'Europe in question' Discussion Paper 39, p. 31.

93 See D. Leczykiewicz (2015), n. 92 p. 21 under footnote 48, emphasis added by the authors.

94 And also in the EU Charter of fundamental rights (chapter on solidary).

95 See Magdalena Bernaciak (2012), 'Social Dumping? Political catchphrase or threat to labour standards', WP 2012/o6, p. 26. 
The main point to stress, from the perspective we have chosen in this chapter, is that the posting of workers narrative is not about workers competing on wage levels, but about service providers competing (unfairly) on wage levels and employment conditions of their employees. In our view, the most legally coherent and socially sustainable way to 'upgrade' the narrative on posted 'low-waged' workers, would be to acknowledge posted EU workers as self-standing beneficiaries of free movement of workers rights, who deserve to be protected by the prohibition of discrimination based on nationality as much as any person who falls under the scope of EU law. ${ }^{96}$ As a second best, a revised PWD, based on 'equal pay for equal work at the same location', may be assessed as an important step in the right direction, in particular in combination with other improvements such as a defined time limit of twelve months. ${ }^{97}$ If effectively applied and enforced, this may lead to a loss of interest in 'posting as a cheap business model' because that would not be so lucrative anymore. Ideally, such a development would go hand in hand with hiring cross-border workers directly in the host state, based on the 'superior narrative' of the free movement of workers, and/or with bringing more jobs to the worker instead of workers to the jobs, both in (what are currently known as) 'host states' and 'sending states'.

\section{Bibliography}

Barnard, C. (2009), 'Internal market v. labour market: a brief history', in M. de Vos (ed.), European Union Internal Market and Labour law: Friends or Foes?, Antwerp: Intersentia, pp. 19-43.

Barnard, C. (2014), 'Free movement of natural persons and citizenship', in C. Barnard and S. Peers (eds.), European Union Law, Oxford: Oxford University Press: 2017 pp. 369-408.

96 We acknowledge that this would bring back to the stage the initial problem, which was solved by the ruling in VanderElst regarding third-country nationals legally residing and working in an EU Member State. These workers are not covered by the freedom to move as a worker enshrined in Art. 45 TFEU, but have, under the current narrative on posting of workers, a de facto right to movement derived from their EU-based employer, albeit a 'passive' one. They can, however, move as a worker once they obtain long-term resident status. For the interaction between Art. 45 TFEU and PIL, see e.g. Houwerzijl (2014), n. 14, pp. 109-111.

97 Combined with other 'most beneficial ingredients' from a social point of view in the provisional agreement between the Council, Parliament and Commission of March 2018, such as that travel, board and accommodation costs should be paid by the employer and not deducted from workers' salaries, and that the accommodation conditions for posted workers should be decent, and in line with national rules. 
Bernaciak, M. (2012), 'Social Dumping? Political catchphrase or threat to labour standards,' ETUI Working Paper 2012/o6.

Berntsen, L.E. (2015), Agency of labour in a flexible pan-European labour market: A qualitative study of migrant practices and trade union strategies in the Netherlands Groningen (PhD Thesis) Groningen: University of Groningen, SOM research school.

Biagi, M. (1998), 'The “Posted Workers' EU Directive”', in R. Blanpain (ed.), The Bulletin of Comparative Labour Relations in the European Union, pp. 173-180.

Cremers, J. (2011), In Search of Cheap Labour in Europe: Working and living conditions of posted workers, Brussels: CLR/EFBWW/International Books.

Cremers, J.; J.E. Dølvik; and G. Bosch (2007), 'Posting of workers in the single market: attempts to prevent social dumping and regime competition in the EU', Industrial Relations Journal 6, pp. 524-541.

EU Observer (20 July 2016), Eastern EU states lose battle on workers' pay, Brussels. European Commission (2016), Revision of the Posting of Workers Directive-frequently asked questions, Strasbourg.

Everling, U. (1963), Das Niederlassungsrecht im Gemeinsamen Markt, Berlin: Verlag Franz Vahlen.

Evju, S. (2010), 'Revisiting the Posted Workers Directive: Conflict of Laws and Laws in Contrast', Cambridge Yearbook of European Legal Studies, 12 pp. 151-182. Gormley, L. (1992), 'Freedom of Establishment and Freedom to Provide Services: Workers and Services Distinguished', European Law Review, 17(1) pp. 63-67.

Hoek, A. van (2018), 'Re-Embedding the Transnational Employment Relationship: A Tale about the Limitations of (EU) Law?', Common Market Law Review 55, no. 2, 449-87.

Hoek, A.A.H. van and Houwerzijl, M.S. (2011), Comparative Study on the legal aspects of the posting of workers in the framework of the provision of services in the European Union, Report to the European Commission.

Hoek, A.A.H. van and Houwerzijl, M.S. (2016), 'Where do EU mobile workers belong, according to Rome I and the (E)PWD', in H. Verschueren (ed.), Residence, employment and social rights of mobile persons: on how EU law defines where they belong, Antwerp: Intersentia, pp. 215-253.

Houwerzijl, M.S. (2005), De Detacheringrichtlijn (PhD thesis) Tilburg: Tilburg University, Deventer: Kluwer.

Houwerzijl, M.S. (2014), 'Regime shopping across (blurring) boundaries', in S. Evju (ed.), Regulating Transnational Labour in Europe: The quandaries of multilevel governance, Oslo: Skriftserie nr. 196.

Houwerzijl, M.S.; E. Traversa; and F. Henneaux (December 2016), A hunters game: How policy can change to spot and sink letterbox-type practices, Brussels: commissioned by the ETUC. 
Kukoveck, D. (2014), 'Hierarchies as law', Columbia Journal of International Law, 21 pp. 131-193.

Leczykiewicz, D. (2015), 'Conceptualizing conflict between the economic and social in EU law after Viking and Laval', in M. Freedland and J. Prassl (eds.), $E U$ law in the Member States: Viking, Laval and beyond, Oxford: Hart Publishing.

Monti, M. (May 2010), A new strategy for the single market, at the service of Europe's economy and society. Retrieved from: http//:ec.europa.eu/bepa/pdf/ monti_report_final_10_05_2010_en.pdf.

Ooik, R.H.van (1999), De keuze der rechtsgrondslag voor besluiten van de Europese Unie (PhD Thesis Universiteit Utrecht), Deventer: Kluwer.

Ostaijen, M.M.A.C. van (2017), Worlds between Words: the politics of intra-European movement discourses, Erasmus University Rotterdam, retrieved from http://hdl. handle.net/1765/99986.

Ostaijen, M.M.A.C. van; U. Reeger; and K. Zelano (2017), 'The commodification of mobile workers in Europe - a comparative perspective on capital and labour in Austria, the Netherlands and Sweden', Comparative Migration Studies, 5(6) pp. 1-22.

Reynolds, S. (2016), 'Explaining the constitutional drivers behind a perceived judicial preference for free movement over fundamental rights' Common Market Law Review 3 pp. 643-677.

Ruhs, M. (2013), The Price of Rights: Regulating International Labour Migration, Princeton University Press.

Somek, A. (2011), 'The social question in a transnational context', London School of Economics 'Europe in question' Discussion Paper, No. 39.

Tusk, D. (5 July 2016), 'Freedom of movement is non-negotiable if Britain wants access to single market', The Independent.

Vignes, D. (1961), 'Le droit d'établissement et les services dans la C.E.E.' Annuaire Français de Droit International, 7 pp. 674-675.

Wagner, I. (2015), Posted Work and Deterritorialization in the European Union: A study of the German Construction and Meat Industry, (PhD Thesis) Groningen: University of Groningen, SOM research school.

Weber, T. (14 May 2016), 'Third time's a charm? National Parliaments form bloc against posted workers directive', Leiden Law Blog, available at http://leidenlawblog.nl/articles/third-times-a-charm-national-parliamentsform-bloc-against-posted-workers-d.

Zahn, R. (2017), 'Revision of the Posted Workers Directive: a Europeanisation Perspective', Cambridge Yearbook of European Legal Studies 5, pp. 5-24. 
About the Authors

Mijke Houwerzijl is professor of Labour Law at Tilburg University and holds a chair in Comparative and European Labour Law at the University of Groningen.

Annette Schrauwen holds a chair of European Integration, in particular citizenship law and history, at the University of Amsterdam. 